\title{
THE IMPACTS OF SOCIAL NETWORKING SITES IN HIGHER LEARNING
}

\author{
Mohd Ishak Bin Ismail and Ruzaini Bin Abdullah Arshah
}

\author{
Faculty of Computer Systems \& Software Engineering, University of Malaysia Pahang, \\ 26300 Gambang, Pahang, Malaysia \\ Email: ishak860825@gmail.com \\ Phone: +60168013634
}

\begin{abstract}
Social networking sites, a web-based application have permeated the boundary between personal lives and student lives. Nowadays, students in higher learning used social networking site such as Facebook to facilitate their learning through the academic collaboration which it further enhances students' social capital. Social networking site has many advantages to improve students' learning. To date, Facebook is the leading social networking sites at this time which it being widely used by students in higher learning to communicate to each other, to carry out academic collaboration and sharing resources. Learning through social networking sites is based on the social interaction which learning are emphasizing on students, real world resources, active students participation, diversity of learning resources and the use of digital tools to deliver meaningful learning. Many studies found the positive, neutral and negative impact of social networking sites on academic performance. Thus, this study will determine the relationship between Facebook usage and academic achievement. Also, it will investigate the association of social capital and academic collaboration to Facebook usage.
\end{abstract}

Keywords: Social networking sites; Facebook; social capital; academic achievement.

\section{INTRODUCTION}

The rapid development of information and communication technology has emerged into a new communication trend that keep people to stay connected and allow sharing of information anywhere and anytime. Looking back on the way of internet's users used to communicate to each other, especially before the social networking sites open up global communication, they are mainly relied on email, chat rooms, instant messaging, forums, guestbook, blogs and tagboards to convey their messages. At that time, these webs trend are the most reliable and compelling way for them to keep in touch. However, the fast over changing of technology required a new solution in order to meet the present needs in vast communication. Nowadays, people around the world have embraced social networking sites into their daily lives which this trend will continue to proliferate as it makes communication becomes easier and more efficient.

Social networking site (SNS) is an online web-based application that continues to be a popular way of communication especially among internet's users up to this present. The features in current social networking sites are developed based on the old day webs trend which somehow we can find out more than one of these webs trend in single social networking site. For example, the email functionality has embedded in Facebook Messaging and Twitter Direct Messaging. Also, Instant Messaging is equivalent to Facebook Chat and Twitter in present day. With this new look of social 
networking sites, people can simultaneously checking their emails and chatting in a single web application rather than using two different applications at the same time.

As social networking sites are getting more and more popular, people become aware on the important of adopting social networking sites in their lives. People started to adopt social networking sites to share and exchange ideas, form groups (Hew, 2011) as well as to make friends or reconnect old friends around the globe. Today, social networking sites become ubiquitous ways of communication which they have attracted people around the world to take part. Thus, it is not something unusual in this present day to have people who spend a lot of their time in front of social networking sites, accessing information on their digital assets.

The role of social networking sites is not limited to social interaction only. In present, social networking sites have found their way in business, learning, works and other purposes. Higher learning such as universities and colleges has noticed the significant of social networking sites to facilitate learning and achieve their institutional goals. For learning purpose, social networking site such as Facebook is able to promote high constructivism (Buzzetto-More, 2012). Constructivism is a student-centered learning which students direct their learning. Since Facebook is mainly designed for social interaction, students can easily perform their online collaboration academic when using Facebook. They are free to ask anyone in the Facebook groups that they think able to give opinions or views.

Social interaction through social networking sites is possibly established in universities and colleges because of the large number of students that come from different backgrounds, cultures, and social groups. Thus, every student might have different views on certain discussed problems or topics based on their existing experiences. With the high number of individuals participate in a discussion, learning will be better and more effective (Kreijns et al., 2007).

The vast adoption of social networking sites by students in higher learning has given rise to a great concern related to their academic achievement. Since social networking site is mainly designed for social interaction, students will simultaneously use their social networking sites for both academic disclosure and social disclosure. Thus, this study will seek information about how social networking site will affect students' academic achievement and how much socialization and academic collaboration influence the usage of social networking site among students in higher learning.

\section{LITERATURE REVIEW}

\section{Social Networking Sites}

Social networking site (SNS) can be categorized as a tool in social media. According to Boyd and Ellison (2008), "SNS can be defined as web-based services that allow individuals to construct a public or semi-public profile within a bounded system, articulate a list of other users with whom they share a connection, and view and traverse their list of connections and those made by others within the system". In summary, SNS can be defined as any web-based services that provide means for the users to interact through internet. Based on the these definitions, SNS can be described as the internet based platform that allow people to perform interaction among other social networking sites users using the available embedded features. 
Current social networking sites platform includes Facebook, QQ, WhatsApp, QZone, Facebook Messenger, WeChat, LinkedIn, Skype, Google+, Instagram, Baidu Tieba, Twitter, Viber, Tumblr, SnapChat, LINE, Sina Weibo, and Vkontakte. The top 10 social networking sites are reported in Table 1 based on the online survey conducted as of March 2015.

Table 1. Top 10 social networking sites.

\begin{tabular}{ccc}
\hline Rank & Social networking sites & Number of active user (million) \\
\hline 1 & Facebook & 1,415 \\
2 & QQ & 829 \\
3 & WhatsApp & 700 \\
4 & QZone & 629 \\
5 & Facebook Messenger & 500 \\
6 & WeChat & 468 \\
7 & LinkedIn & 347 \\
8 & Skype & 300 \\
9 & Google+ & 300 \\
10 & Instagram & 300 \\
\hline
\end{tabular}

\section{An Overview of Facebook}

The widespread of Facebook across global communities makes it possible to connect anyone in different locations. The early definition of Facebook is referred to an online directory that connects people through social networks at colleges and universities (Zukerberg, 2005). The early purpose of Facebook invention in 2004 is mainly to connect students in universities. At that time, Facebook was adopted by institutions in the higher education sector (Hew, 2011). After several years of its invention, Facebook has become student choice for communication purpose (Roblyer et al., 2010). In the present day, Facebook is widely used by the public and users from other countries (Hew, 2011). Facebook have recently improved in term of usability and functionality due to the over changing needs in global communication.

\section{Facebook Usage by Students}

In several studies, students are using Facebook for many purposes. According Kalpidou et al (2011) college students use Facebook to create new and maintain old relationships, obtain information related to the social events that occur on campus and social college adjustment. For example, students can get information about the latest event or issue in their learning place through post or comment sent in the Facebook. Another study highlighted that student use Facebook to create a social presence (Cheung, Chiu, and Lee, 2011) while Nadkarni and Hofmann (2012) concluded that people use Facebook usage to fulfill need to belong and need for self-presentation. Based on these studies, students in higher learning embraced Facebook mainly for social interaction such as making friends, self-satisfaction and sharing of first-hand information.

\section{Facebook Usage and Academic Achievement}

Many researchers give different views on the influence of Facebook to academic achievement. Academic achievement refers to grade point average (GPA). GPA is the 
most acceptable way to evaluate students' performance. Previous research by Kolek and Saunders (2008) found no difference in overall grades between Facebook users and nonusers. In addition to this, Facebook users with lower grade tended to spend less time on their studies compared to those who did not use Facebook (Kirschner and Karpinski, 2010). Junco (2012a) found a negative association between time spent on Facebook and grades. The same result resembles the study result by Paul et al (2012) on the impact of time spent on the online networking sites to academic performance. They found negative association between time spent and academic performance. In contrast, Ainin et al. (2015) proved the positive impact on Facebook usage on academic performance.

\section{Social Capital and Facebook Usage}

Social capital can be defined as the resources obtained from their relationships and interactions such as emotional support (Ellison et al., 2011). According to McPherson et al (2014) social capital is related to improved self-esteem, reduced psychological and behavioral problems, and improved quality of life. Social capital can be appeared within the relationship among close friends, family members and society members. Commonly, social capital can be categorized as positive social capital and negative social capital. As reflected by its name, positive social capital will encourage people to inherit good manners as a response to their surroundings. On the other hand, negative social capital will influence people to act negatively to their surroundings.

The main premise of social capital is social networks have value. Since, learning activities by social networking sites are based on social interaction to gain knowledge, high number of friends will allow them to exchange knowledge effectively. Previous study addressed that social capital is positively affect learning outcomes (Lu et al., 2013). Students feel more of a connection to their institution if they have strong social capital, which is related to more positive educational outcomes (Pascarella and Terenzini, 2005).

\section{Academic collaboration and Facebook Usage}

As digital natives, students in higher learning intensely use the social networking sites for academic collaboration (Hamid et al., 2015), communicating and entertainment. Facebook, for example, has allowed students to get information about their learning community, perform collaborative learning, sharing their photo and knowledge (Hew, 2011) and submit their assignment. In addition, the use of social networking sites such as Facebook in higher learning have totally changed the role of students in their learning and the way learning contents can be acquired. At present, students are greatly responsible to their own learning and most of the learning occurred throughout the close interactions among individual and individual as well as among individual and group.

Past studies have addressed that learning via Facebook have enormous potential to enhance teaching and learning in higher learning (Hamid et al., 2015) which it can be used to foster collaborative learning and increase interactions between students. Irwin et al (2012) indicated that Facebook may be an appropriate addition to traditional elearning tools. Social networking sites increased the rate and quality of collaboration for students. Collaborative learning is based on social learning theory, where learning takes place when learners interact among themselves. Thus, most of the collaborative learning activities are designed for group discussions using various communication tools to enhance student critical thinking, problem solving skills and self-reflection (Leow \& 
Neo, 2015). By encouraging the use of social networking sites for academic collaboration, students might get positive effect on their academic achievement (Chawla et al., 2015).

\section{CONCLUSION}

Social networking site offers many valuable benefits to improve learning. However, using Facebook for academic collaboration requires self-control and willingness to follow the ethical guideline. In reality, students are easily exposed to the richness of the information from Facebook which some information is not related to their academic needs. Thus, they will spend more time on exploring this information instead of focusing on their academic needs. As the result, researches have pointed that students who spent more time on Facebook has negative or no impact on their academic performance. The effectiveness of online learning via Facebook is subjective depend on the purpose of its usage. Meaning to say if students intend to use Facebook for academic purposes then they are going to improve their learning experiences. Else, it will produce no or negative impact to their academic achievement.

\section{ACKNOWLEDGEMENTS}

Special thanks to faculty especially to my supervisor whose support and guidance always inspire me to proceed smoothly.

\section{REFERENCES}

Ainin, S., Naqshbandi, M. M., Moghavvemi, S., \& Jaafar, N. I. (2015). Computers \& Education Facebook usage, socialization and academic performance. Computers \& Education, 83, 64-73. doi:10.1016/j.compedu.2014.12.018

Boyd, D.M. \& Ellison, N.B. (2008). Social network sites: Definition, history and scholarship. Journal of Computer-Mediated Communication. 13:210-230.

Buzzetto-More, N. a. (2012). Social networking in undergraduate education. Interdisciplinary Journal of Information, Knowledge, and Management, 7, 63-90.

Chawla, S., Pawlina, W., Hafferty, F., \& Lachman, N. (2015). The Hidden Learning Environment: Effect of informal student networks on team performance in a Gross Anatomy Course. The FASEB Journal, 29(1 Supplement), 344-2.

Cheung, C. M. K., Chiu, P. Y., \& Lee, M. K. O. (2011). Online social networks: why do students use Facebook? Computers in Human Behavior, 27(4), 1337e1343

Ellison, N. B., Steinfield, C., \& Lampe, C. (2011). Connection strategies: social capital implications of Facebook-enabled communication practices. New Media \& Society. http:// dx.doi.org/10.1177/1461444810385389.

Hamid, S., Waycott, J., Kurnia, S., \& Chang, S. (2015). Understanding Students' Perceptions on the Benefits of Online Social Networking Use for Teaching and Learning. The Internet and Higher Education, 26, 1-9.

Hew, K. F. (2011). Students' and teachers' use of Facebook. Computers in Human Behavior, 27(2), 662e676.

Irwin, C., Ball, L., Desbrow, B., \& Leveritt, M. (2012). Students' perceptions of using Facebook as an interactive learning resource at university. Australasian Journal of Educational Technology, 28(7), 1221-1232. 
Junco, R. (2012a). Too much face and not enough books: The relationship between multiple indices of Facebook use and academic performance. Computers in Human Behavior, 28(1), 187-198.

Kalpidou, M., Costin, D., \& Morris, J. (2011). The relationship between Facebook and the well-being of undergraduate college students. CyberPsychology, Behavior, and Social Networking, 14(4), 183e189.

Kolek, E. A., \& Saunders, D. (2008). Online disclosure: An empirical examination of undergraduate Facebook profiles. NASPA Journal, 45(1), 1-25.

Kirschner, P. A., \& Karpinski, A. C. (2010). Facebook and academic performance. Computers in Human Behavior, 26(6), 1237-1245.

Kreijns Karel; Kirschner Paul A.; Jochems Wim; van Buuren Hans (2007) Measuring perceived sociability of computersupported collaborative learning environments, Computers \&amp; Education, Volume 49, Issue 2, September 2007, Pages 176192

Leading social networks worldwide as of March 2015, r. (2015). Social networks: global sites ranked by users 2015 | Statistic. Statista. Retrieved 31 May 2015, from http://www.statista.com/statistics/272014/global-social-networks-ranked-bynumber-of-users/

Leow, F. T., \& Neo, M. (2015). Redesigning the Classroom Environment to Enhance Students' Collaborative Learning Activities. In Emerging Issues in Smart Learning (pp. 267-274). Springer Berlin Heidelberg.

Lu, J., Yang, J., \& Yu, C. S. (2013). Is social capital effective for online learning? Information and Management, 50(7), 507-522. doi:10.1016/j.im.2013.07.009

McPherson,K.E.,Kerr,S.,McGee,E.,Morgan,A.,Cheater,F.M.,McLean,J.,etal.(2014). The association between social capital andmental health and behavioural problems in chil- dren and adolescents: an integrative systematic review. BMC Psychology, 2(7), 1-16.

Nadkarni, A., \& Hofmann, S. G. (2012). Why do people use Facebook? Personality and Individual Differences, 52(3), 243e249.

Paul, J. A., Baker, H. M., \& Cochran, J. D. (2012). Effect of online social networking on student academic performance. Computers in Human Behavior, 28(6), 21172127. doi:10.1016/j.chb.2012.06.016

Pascarella, E. T., \& Terenzini, P. T. (2005). How college affects students. San Francisco, CA: Jossey-Bass.

Roblyer, M. D., McDaniel, M., Webb, M., Herman, J., \& Witty, J. V. (2010). Findings on Facebook in higher education: A comparison of college Zuckernberg. 